\title{
Assessment of the Physico-mechanical, Thermal, and Morphological Properties of Rubber Wood Modified with Silica Sol in Combination with GU/GMU Resins
}

\author{
Lijuan Ping, ${ }^{\text {a }}$ Yubo Chai, Bailing Sun, ${ }^{*}$ and Junliang Liu *
}

\begin{abstract}
Rubber wood was modified with both a combination of silica sol and glyoxal urea (S-GU), and a combination of silica sol and glyoxal melamine urea (SGMU). The physico-mechanical properties were measured. Thermal properties, chemical molecular structure, and cellular morphology were analyzed via thermogravimetry (TG), differential scanning calorimetry (DSC), Fourier transform infrared spectroscopy (FTIR), and scanning electron microscopy (SEM). The weight percent gain (WPG) increased as the concentration of the impregnated aqueous solutions increased. The S-GMU treated wood exhibited a greater WPG than the S-GU treated wood at the same concentration. Anti-swelling efficiency (ASE), modulus of elasticity (MOE), and modulus of rupture (MOR) of treated wood increased as the WPG increased. The highest ASE value was $42.0 \%$, for the S-20\%GMU treated wood, which was higher than the S-20\%GU treated wood. The MOR of the S$20 \%$ GMU treated wood was improved by $25 \%$. Thermal analyses showed the thermostability of S-GMU treated wood increased. FTIR results indicated the presence of $\mathrm{C}-\mathrm{N}$ and $\mathrm{Si}-\mathrm{O}-\mathrm{Si}$ bonds in the S-GMU treated wood, and the lignin and carbohydrates degraded to a certain extent. SEM imaging showed that the S-GMU was deposited in the cell lumen and cell wall. Therefore, this study produced evidence of an improvement in the physico-mechanical and thermal properties of S-GMU treated wood.
\end{abstract}

Keywords: Rubber wood; Modification; Silica sol; Glyoxal-urea resin; Glyoxal-melamine-urea resin

Contact information: Research Institute of Wood Industry, Chinese Academy of Forestry, Beijing 100091 China; *Corresponding authors: sunbling@126.com; liujunliang@caf.ac.cn

\section{INTRODUCTION}

Rubber trees (Hevea brasiliensis), which are indigenous to the Amazon valley of South America, have been widely cultivated in China since the latter half of the 20th century (Qin et al. 2017). Currently, they are primarily planted in Hainan, Yunnan, and other southern Chinese provinces, covering more than 1.18 million ha (Jiang et al. 2018). Generally, rubber trees are replanted every 25 years to 30 years, when they become uneconomical for harvesting for latex production. The felled trees have been used as lumber for furniture and building materials in recent years (Salla et al. 2012; Min 2019). However, the rubber wood has inferior dimensional stability compared to other woods and is prone to decay, warp deformation, and cracks. Modifying the rubber wood is a good method for improving its properties and achieving a greater range of potential use.

Various chemical modifications have been proposed, including esterifications (Berube et al. 2018), etherifications (Hill 2007), silylation (Donath et al. 2006), and impregnation with thermosetting resin (Wang et al. 2017). Some of those have been used in a commercial application, such as wood modification via a thermosetting resin. Numerous studies have used low-molecular-weight phenol-formaldehyde resin (PF), 
melamine-formaldehyde resin (MF), urea-formaldehyde resin (UF), or melamine-ureaformaldehyde resins (MUF) to improve the physico-mechanical and thermal properties of various woods (Deka and Saikia 2000; Yue et al. 2016). However, because formaldehydebased thermosetting resins pose major environmental concerns, it is necessary to replace the toxic formaldehyde in the synthesis of environmentally friendly wood adhesives. Among the various aldehydes available, the usage of glyoxal has yielded the best results, as it is nontoxic, has a low cost, is nonvolatile, and is easily biodegradable (YounesiKordkheili and Pizzi 2016; Younesi-Kordkheili and Pizzi 2017). Due to its two active merged aldehyde groups, it can be used to glyoxylate the lignins in cell walls or cross-link with the hydroxyl groups in cellulosic materials via a hemiacetal or acetal reaction in the presence of a catalyst (Lee and Kim 2005; Navarrete et al. 2013). Some researchers have used glyoxal as a cross-linking agent for wood modification, and all modified woods exhibited excellent dimensional stability and poor moisture absorption. The acidity of glyoxal at high curing temperatures may cause hydrolysis or degradation of the cell wall (Nakano 1993; Dong et al. 2014). Glyoxal-based synthetic resins are also much more environmentally friendly than formaldehyde-based thermosetting resins. Glyoxal readily combines with urea to form synthesized GU resin, which improves the mechanical properties of wood samples. However, the anti-leachability of GU-treated woods decreases (Yan et al. 2015).

Silicon is an abundant element that can form a wide variety of inorganic compounds. Modification with inorganic silicon compounds can enhance the dimensional stability of the wood and improve its antimicrobial properties and fire resistance (Saka et al. 1992; Mai and Militz 2004; Donath et al. 2006). Silica itself is hydrophilic. To increase the hydrophobicity of the inorganic silica particle, the surface is modified by different silane compounds (Hu et al. 2004). Nano-SiO 2 , was used in studies, as well, to improve the mechanical, water uptake, dimensional stability, hardness, and flammability properties of wood-polymer composites (WPCs) (Devi et al. 2012; Dong et al. 2014). In addition, impregnating wood with silica sol. The nano-sized sols are easily transportable into wood and from coatings on the inner wood surfaces (Liu et al. 2015). The silica particles improve the surface hydrophobicity via the presence of film-forming substances (Kumar et al. 2017). Wood modification with silica sol can also enhance the flexure properties and surface hardness of the wood, as well as improving its dimensional stability, decay resistance, and water-related properties (Temiz et al. 2006; Tejado et al. 2007; Qu et al. 2011; Kumar et al. 2016).

Organic-inorganic treatment is an emerging method of wood modification via physical-chemical methods to achieve improved dimensional stability, mechanical properties, and the addition of new functions. For this purpose, an environment-friendly GMU resin was synthesized from glyoxal, melamine, and urea, and the resulting resin was applied to rubber wood in combination with silica sol for the first time. The aim of this study was to investigate the physico-mechanical, thermal, and morphological properties of the modified rubber wood and to better understand the modification mechanism via Fourier transform infrared spectroscopy (FTIR), thermogravimetry (TG), differential scanning calorimetry (DSC), scanning electron microscopy (SEM), and energy dispersive X-ray (EDX) analysis. 


\section{EXPERIMENTAL}

\section{Materials}

The rubber wood (Hevea brasiliensis) was collected from Ledong County, Hainan Province, China. Rubber wood blocks with dimensions of $300 \mathrm{~mm} \times 20 \mathrm{~mm} \times 20 \mathrm{~mm}$ (longitudinal $\times$ radial $\times$ tangential) were prepared from clear, defect-free wood. To reduce deviation, all samples were chosen from the same timber and machined (sawn and planed) at the same time.

The silica sol was obtained from the Guangzhou Suize Environment Protection Technology Co., Ltd. (Guangdong, China) with an average particle size of $14 \mathrm{~nm}$ to $30 \mathrm{~nm}$ and a $\mathrm{pH}$ range of 9.5 to 10.5 . The glyoxal-urea $(\mathrm{GU})$ resin and glyoxal-melamine-urea (GMU) resin with a solid content of $40 \%$ (a pH: 7.5 to 8.5 , a viscosity of $2.5 \mathrm{mPa} \cdot \mathrm{s}$ to 5.0 $\mathrm{mPa} \cdot \mathrm{s}$, a water miscibility greater than 10 , and a shelf life of $30 \mathrm{~d}$ ) were both synthesized in a laboratory. All of the chemicals and solvents used in this study were of analytical grade.

\section{Preparation of the Modified Wood}

Preparation of impregnation solutions

The impregnated aqueous solutions were obtained by mixing silica sol and GU resin or GMU resin under an ultrasonic wave. The aqueous solutions were ratioed as follows: (1) $10 \%$ silica sol; (2) $10 \%$ silica sol and 5\%, 10\%, or $20 \%$ GU resin; and (3) $10 \%$ silica sol and $5 \%, 10 \%$, or $20 \%$ GMU resin.

\section{Samples treatment}

All of the samples were initially dried at $103{ }^{\circ} \mathrm{C} \pm 2{ }^{\circ} \mathrm{C}$ to ensure a constant weight. Afterwards the dimensions and weights were measured.

\section{Impregnation}

The samples were placed into a stainless reactor and subjected to vacuum for 30 min. The respective impregnation aqueous solution was introduced to the stainless reactor, and the sample was submerged under a pressure of $0.95 \mathrm{MPa}$ for $5 \mathrm{~h}$ at room temperature. After impregnation, the pressure of the stainless reactor was relieved, and the aqueous solution was removed.

\section{Polymerization}

The wood samples were wrapped with aluminum foil, kept at room temperature for 4 to $5 \mathrm{~d}$, and placed into an oven at $100{ }^{\circ} \mathrm{C}$ for $24 \mathrm{~h}$ for polymerization. Afterwards, the aluminum foil was removed and the sample was dried at, $103{ }^{\circ} \mathrm{C} \pm 2{ }^{\circ} \mathrm{C}$ until constant weight was obtained. The dimensions and weights were then measured.

\section{Physico-Mechanical Properties}

Weight percentage gain (WPG) was used as an essential parameter for the characterization of wood samples. The WPG was calculated based on Eq. 1,

$$
W P G=\frac{W_{1}-W_{0}}{W_{0}} \times 100 \%
$$

where $W_{0}$ is the oven-dried weights of samples before modification and $W_{1}$ is the ovendried weights of samples after modification. Each type of sample was measured by 15 tests. 
Dimensional stability was evaluated by measurement of anti-swelling efficiency (ASE). Each type of sample was measured with 15 tests. ASE was evaluated according to Chinese standard GB/T 1934.2 (2009). The ASE was calculated as follows, according to Eq. 2,

$$
A S E=\frac{S_{0}-S_{1}}{S_{0}} \times 100 \%
$$

where $S_{0}$ is the volume expansion of the untreated samples and $S_{1}$ is the volume expansion of the treated samples. During the tests, the dimensions of each specimen was $20 \mathrm{~mm} \times 20$ $\mathrm{mm} \times 20 \mathrm{~mm}$ (L x T x R).

Mechanical testing was conducted using an INSTRON 5582 universal testing machine (Instron Co., Grove City, PA, USA). The modulus of elasticity (MOE) and the modulus of rupture (MOR) were determined via a three-point bending test with specimens measuring $300 \mathrm{~mm} \times 20 \mathrm{~mm}$ x $20 \mathrm{~mm}$ ( $\mathrm{L} \times \mathrm{T}$ x R) according to Chinese standards GB/T 1936.2 (2009) and GB/T 1936.1 (2009). Fifteen replicates were tested for each treatment.

\section{Thermal Analysis}

The treated and untreated wood samples were ground into powder and sieved with a 40 mesh to 60 mesh size. Thermogravimetry and differential scanning calorimetry were performed under a $\mathrm{N}_{2}$ atmosphere at a heating rate of $10{ }^{\circ} \mathrm{C} / \mathrm{min}$ (from room temperature to $800{ }^{\circ} \mathrm{C}$ ) using an SDT Q600 (simultaneous DSC-TGA) thermal analyzer (TA Instruments, Waters LLC, New Castle, DE, USA).

\section{Microstructural Characterization}

Scanning electron microscopy (Hitachi, S-4800, Toyko, Japan) was performed to characterize the distribution in the cross sections, radial sections, and tangential sections of the silica sol-treated wood and the S-20\% GMU-treated wood. The elemental distribution and contents of the untreated and treated wood were analyzed via a SEM (Quanta, FEG 650, Hillsboro, OR, USA) linked to an energy-dispersive X-ray analyzing system with an Oxford Instruments X-maxN 150 EDX detector with an acceleration voltage of $5 \mathrm{kV}$. The scanning surface of the samples had dimensions of $2 \mathrm{~mm} \times 2 \mathrm{~mm} \times 5 \mathrm{~mm}$ and were smoothed with a sliding microtome.

\section{RESULTS AND DISCUSSION}

\section{Physico-Mechanical Properties}

As shown in Table 1, the WPG of the modified wood increased as the concentration of the silica sol-GU/ GMU aqueous solutions increased. The WPG of the modified wood samples impregnated with silica sol combined with GU ranged from $18.4 \%$ to $24.2 \%$, which were higher than the WPG of the modified wood samples impregnated with only silica sol. A similar trend was obtained by Yan et al. (2015) for poplar wood with GU combined with nano-SiO 2 . However, the wood treated with $\mathrm{S}-\mathrm{GMU}$ exhibited a greater WPG than the S-GU treated wood at the same concentration, and the highest WPG was $28.3 \%$ (S-20\% GMU). Furthermore, the ASE of the modified wood increased as the WPG increased. The highest ASE was $42.02 \%$ for the S-20\% GMU treated wood samples, which was higher than the other wood samples subjected to silica sol and S-GU treatments. For the mechanical properties, the MOE and MOR of the modified wood samples increased as

Ping et al. (2020). "Properties of modified rubber wood," BioResources 15(4), 8051-8064. 8054 
the WPG increased, as shown in Table 1. The MOE and MOR of the untreated wood samples were on average $9320 \mathrm{MPa}$ and $91.8 \mathrm{MPa}$, respectively. The MOE and MOR of the wood samples impregnated with a S-20\% GMU solution were $9640 \mathrm{MPa}$ and 115.0 $\mathrm{MPa}$, respectively. The MOR of the S-20\% GMU treated wood samples was improved by $25 \%$ when compared to the untreated wood samples. This indicated that the S-GMU treatment could improve the physico-mechanical properties.

Table 1. The Physico-Mechanical Properties of the Untreated and Treated Wood

\begin{tabular}{|c|c|c|c|c|c|}
\hline Sample & $\begin{array}{c}\text { Treatment } \\
\text { Concentration }\end{array}$ & WPG (\%) & ASE (\%) & MOE (MPa) & MOR (MPa) \\
\hline C & untreated & - & - & $\begin{array}{c}9323.88 \pm \\
348.15\end{array}$ & $91.79 \pm 4.30$ \\
\hline S & $10 \%$ silica sol & $\begin{array}{c}16.29 \pm \\
0.85\end{array}$ & $\begin{array}{c}29.49 \pm \\
1.35\end{array}$ & $\begin{array}{c}9401.38 \pm \\
388.68\end{array}$ & $95.31 \pm 3.78$ \\
\hline S-5GU & $\begin{array}{c}10 \% \text { silica sol + } \\
5 \% \text { GU }\end{array}$ & $\begin{array}{c}18.39 \pm \\
1.05\end{array}$ & $\begin{array}{c}32.12 \pm \\
1.49\end{array}$ & $\begin{array}{c}9442.15 \pm \\
360.48\end{array}$ & $96.82 \pm 3.72$ \\
\hline S-10GU & $\begin{array}{c}10 \% \text { silica sol + } \\
10 \% \text { GU }\end{array}$ & $\begin{array}{c}22.56 \pm \\
1.53 \\
\end{array}$ & $\begin{array}{c}34.12 \pm \\
1.62 \\
\end{array}$ & $\begin{array}{c}9511.28 \pm \\
405.63 \\
\end{array}$ & $99.84 \pm 4.00$ \\
\hline S-20GU & $\begin{array}{c}10 \% \text { silica sol + } \\
20 \% \text { GU }\end{array}$ & $\begin{array}{c}24.21 \pm \\
1.88\end{array}$ & $\begin{array}{c}36.73 \pm \\
1.82\end{array}$ & $\begin{array}{c}9527.91 \pm \\
364.56\end{array}$ & $\begin{array}{c}102.67 \pm \\
5.16\end{array}$ \\
\hline S-5GMU & $\begin{array}{c}10 \% \text { silica sol + } \\
5 \% \text { GMU }\end{array}$ & $\begin{array}{c}20.08 \pm \\
0.88\end{array}$ & $\begin{array}{c}33.16 \pm \\
1.21 \\
\end{array}$ & $\begin{array}{c}9489.28 \pm \\
347.20 \\
\end{array}$ & $98.32 \pm 3.24$ \\
\hline S-10GMU & $\begin{array}{c}10 \% \text { silica sol + } \\
10 \% \text { GMU }\end{array}$ & $\begin{array}{l}25.41 \pm \\
1.37\end{array}$ & $\begin{array}{c}38.69 \pm \\
1.37\end{array}$ & $\begin{array}{c}9542.65 \pm \\
371.26\end{array}$ & $\begin{array}{c}105.69 \pm \\
3.65\end{array}$ \\
\hline S-20GMU & $\begin{array}{c}10 \% \text { silica sol + } \\
20 \% \text { GMU }\end{array}$ & $\begin{array}{c}28.32 \pm \\
1.93 \\
\end{array}$ & $\begin{array}{c}42.02 \pm \\
1.81 \\
\end{array}$ & $\begin{array}{c}9636.20 \pm \\
375.18 \\
\end{array}$ & $\begin{array}{c}114.96 \pm \\
3.81\end{array}$ \\
\hline
\end{tabular}

\section{Thermal Stability}

Thermal analysis was performed to examine the thermal stability of the untreated and treated wood. A better thermal stability means that the wood undergoes pyrolysis at a higher temperature and/or at a slower rate at a particular temperature. As shown in Fig. 1, it could be seen that the TG and differential thermogravimetry (DTG) curves of the thermal degradation process were divided into three mass loss stages. In the first stage, from $30{ }^{\circ} \mathrm{C}$ to approximately $120{ }^{\circ} \mathrm{C}$, the mass loss resulted from the removal of water (Wang et al. 2017). The mass losses were $2.94 \%, 2.10 \%, 1.52 \%$, and $1.71 \%$ for the untreated, silica sol, S-20\% GU, and S-20\% GMU wood samples, respectively. The S-20\% GMU wood samples had a lower value than the untreated wood samples. In the second stage, the temperature range was from $120{ }^{\circ} \mathrm{C}$ to $380{ }^{\circ} \mathrm{C}$, which corresponded primarily to the decomposition of the hemicellulose and cellulose into char residues and $\mathrm{CO}_{2}, \mathrm{CO}, \mathrm{CH}_{4}, \mathrm{CH}_{3} \mathrm{OH}$, as well as $\mathrm{CH}_{3} \mathrm{COOH}$, etc. (Qu et al. 2011). In this stage, the mass loss of the untreated wood was $83.1 \%$, which was higher than the mass loss of the treated wood samples. That indicated that the thermal stability of the treated wood had slightly increased. In addition, the temperature that corresponded to the maximum rate of the mass loss of the treated wood (349.2 ${ }^{\circ} \mathrm{C}$ for the S-20\% GMU samples) was less than the mass loss of the untreated wood samples $\left(363.1^{\circ} \mathrm{C}\right)$, and the maximum rate of mass loss decreased. The third stage occurred in the temperature range of $380{ }^{\circ} \mathrm{C}$ to $800{ }^{\circ} \mathrm{C}$, which was due to the degradation of lignins. The residue char at $800{ }^{\circ} \mathrm{C}$ was $6.15 \%, 26.85 \%, 28.70 \%$, and $32.27 \%$ for the untreated, 
silica sol, S-20\% GU, and S-20\% GMU wood samples, respectively. The increase in residue was more obvious in the S-20\% GMU wood samples.
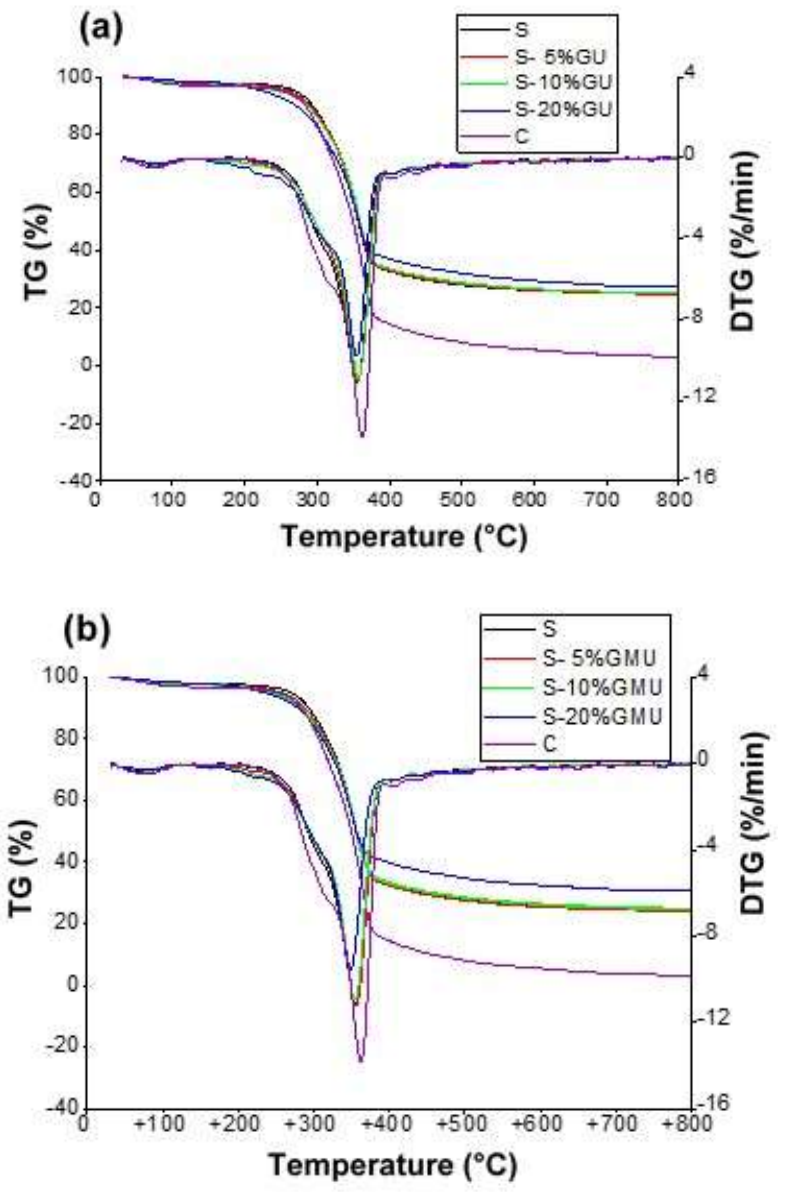

Fig. 1. The TG and DTG curves of the untreated wood samples, silica sol-treated wood samples, and wood samples treated with S-GU (a) and S-GMU (b)

The DSC results for the untreated wood, silica sol-treated wood, S-GU treated wood, and S-GMU treated wood are shown in Fig. 2. As shown, the DSC curve of the untreated and treated wood exhibited a similar curve trend. The endothermic peak at approximately $100{ }^{\circ} \mathrm{C}$ was primarily attributed to the removal of moisture. When compared with the untreated samples and the S-GU and S-GMU treated wood samples, the peak of the silica sol-treated wood was the largest, which indicated a stronger endothermic reaction in the nitrogen atmosphere. In addition, there was an obvious peak range from $300{ }^{\circ} \mathrm{C}$ to $400{ }^{\circ} \mathrm{C}$ in the DSC curve, which primarily corresponded to the decomposition of hemicellulose and cellulose. 
(a)
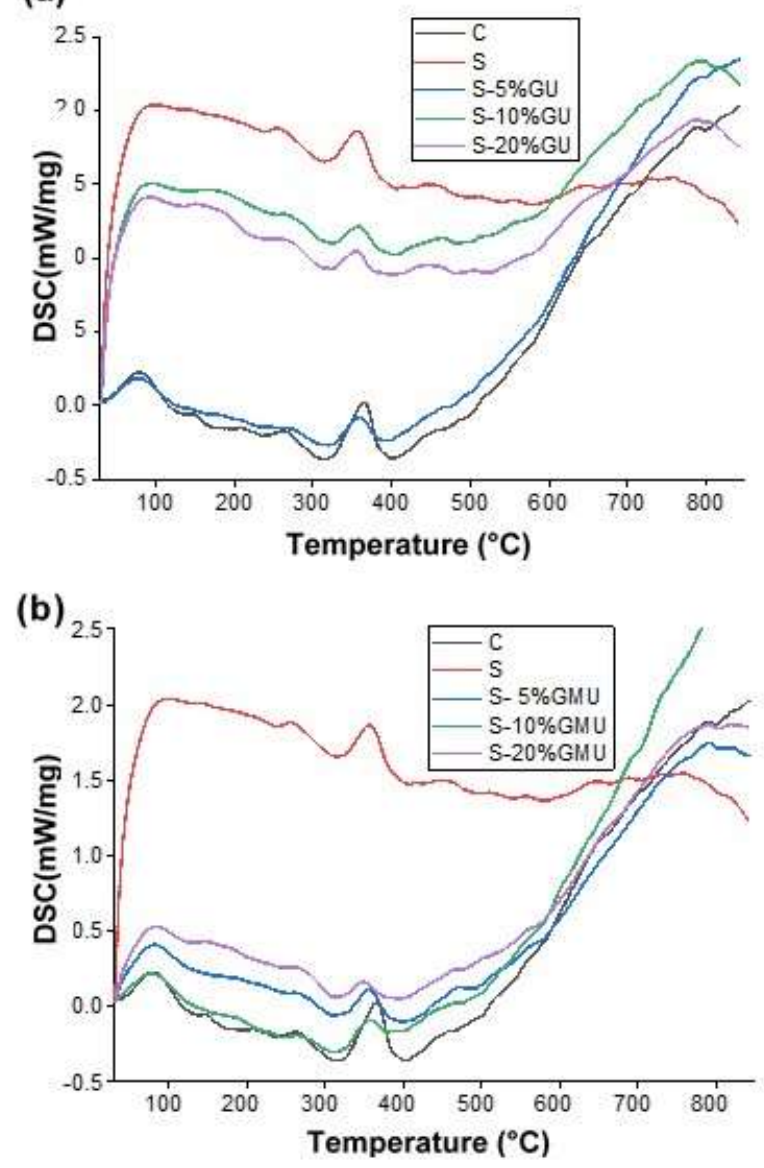

Fig. 2. The DSC of the untreated wood samples, silica sol-treated wood samples, and wood samples treated with S-GU (a) and S-GMU (b)

Table 2 showed the initial pyrolysis temperature $\left(T_{\mathrm{i}}\right)$, peak temperature $\left(T_{\mathrm{m}}\right)$, and peak area $\left(S_{\mathrm{q}}\right)$ of the untreated and treated wood samples. There was a minor difference between the $T_{\mathrm{i}}$ and $T_{\mathrm{m}}$ of the treated and untreated wood samples. However, the $S_{\mathrm{q}}$ values of the S-20\% GMU treated wood samples were lower when compared to the untreated wood samples. In addition, the $S_{\mathrm{q}}$ values were $84.7 \mathrm{~J} \cdot \mathrm{g}^{-1}$ and $23.1 \mathrm{~J} \cdot \mathrm{g}^{-1}$ for the untreated and S-20\% GMU treated wood samples, respectively. 
Table 2. Differential Scanning Calorimetry Analysis

\begin{tabular}{|c|c|c|c|c|c|c|c|c|}
\hline \multirow{2}{*}{ Samples } & \multirow{2}{*}{$\mathrm{C}$} & \multirow{2}{*}{$\mathrm{S}$} & \multicolumn{7}{|c|}{$\mathrm{S}-$} \\
\cline { 4 - 9 } & & & $5 \mathrm{GU}$ & $10 \mathrm{GU}$ & $20 \mathrm{GU}$ & $5 \mathrm{GMU}$ & $10 \mathrm{GMU}$ & 20GMU \\
\hline $\mathrm{Ti} /{ }^{\circ} \mathrm{C}$ & 327.3 & 320.4 & 325.9 & 327.2 & 327.3 & 320.9 & 326.3 & 322.3 \\
\hline $\mathrm{Tm} /{ }^{\circ} \mathrm{C}$ & 365.4 & 356.2 & 359.9 & 358.8 & 355.7 & 355.9 & 356.9 & 348.2 \\
\hline $\mathrm{Sq} / \mathrm{J} \cdot \mathrm{g}-1$ & 84.7 & 82.7 & 41.9 & 31.5 & 22.9 & 73.6 & 40.3 & 25.1 \\
\hline
\end{tabular}

\section{Fourier Transform Infrared Spectroscopy (FTIR) Analysis}

Fourier transform infrared spectroscopy was used to characterize the chemical changes of the wood before and after modification. The assignments of the characterized IR absorption peaks in the wood are shown in Table 3 (Cai et al. 2007; Tejado et al. 2007; Deng et al. 2014a,b; Yan et al. 2015; Jiang et al. 2018; Sun et al. 2019).

Table 3. FTIR Assignments of the Untreated and Treated Wood

\begin{tabular}{|c|c|}
\hline Absorption Band $\left(\mathrm{cm}^{-1}\right)$ & Chemical Structure Assignments \\
\hline 3200 to 3600 & $\mathrm{~N}-\mathrm{H}, \mathrm{O}-\mathrm{H}$ stretching vibration \\
\hline 2900 & C-H stretching vibration \\
\hline 1740 & $\mathrm{C}=\mathrm{O}$ stretching vibration \\
\hline 1656 & $\mathrm{C}=\mathrm{O}$ stretching vibration \\
\hline 1510 & Benzene ring stretching vibration in lignin \\
\hline 1463 & C-N stretching vibration \\
\hline 1244 & C-N and N-H stretching vibration \\
\hline 1055 & C-N stretching vibration \\
\hline 470 & Si-O and Si-O-Si stretching vibration \\
\hline
\end{tabular}

As shown in Fig. 3, the C-H stretching vibration band at $2900 \mathrm{~cm}^{-1}$ from the methyl and methylene groups in the modified wood samples decreased when compared with the band in the untreated wood samples. In comparison with the untreated and silica sol-treated wood, the intensity of the band near $1740 \mathrm{~cm}^{-1}$, which was assigned to $\mathrm{C}=\mathrm{O}$, increased in the S-GMU treated wood samples, which indicated that more $\mathrm{C}=\mathrm{O}$ bonds formed in the modified wood (Yan et al. 2015). In addition, due to the $\mathrm{p}-\pi$ conjugation effect between the $-\mathrm{NH}_{2}$ and $\mathrm{C}=\mathrm{O}$ in the $\mathrm{GU}$ and GMU resins, the $\mathrm{C}=\mathrm{O}$ peak shifted to a lower wavenumber of $1740 \mathrm{~cm}^{-1}$ (Deng et al. 2014a). Furthermore, the bands at $1656 \mathrm{~cm}^{-1}$ and $1510 \mathrm{~cm}^{-1}$ decreased in intensity. The peaks of the S-GU treated wood samples had a more obvious decreased than the S-GMU treated wood samples did. That indicated that the lignins and carbohydrates degraded to a certain extent in the modified wood samples and the S-GMU-treated wood exhibited the least total degradation. 

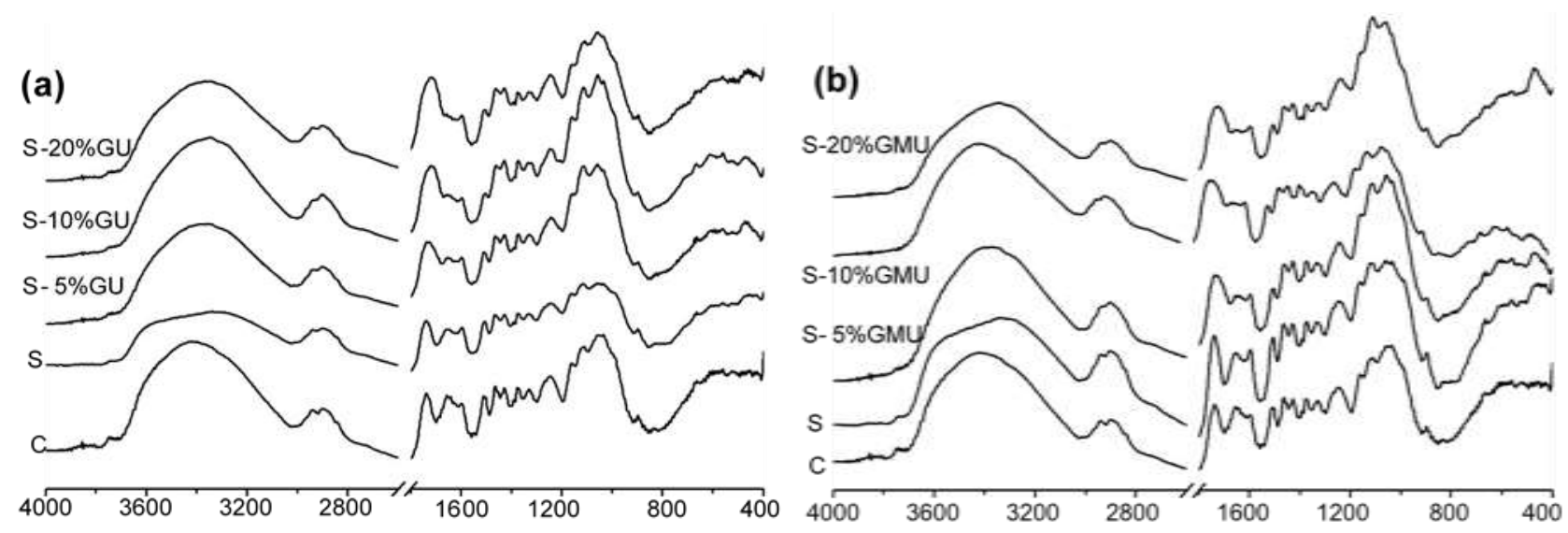

Fig. 3. The FTIR spectra of the untreated wood samples, silica sol-treated wood samples, and wood samples treated with S-GU (a) and S-GMU (b)

\section{Microscopic Analysis}

Figures 4 and 5 show the morphologies of the untreated wood, and the wood with silica sol or S-20\% GMU at different magnifications. Empty cell walls, pits, and distinct lacunae were obvious in the untreated wood (Fig. 5a), while these empty places in the treated wood were occupied by the resin or nano- $\mathrm{SiO}_{2}$ materials.
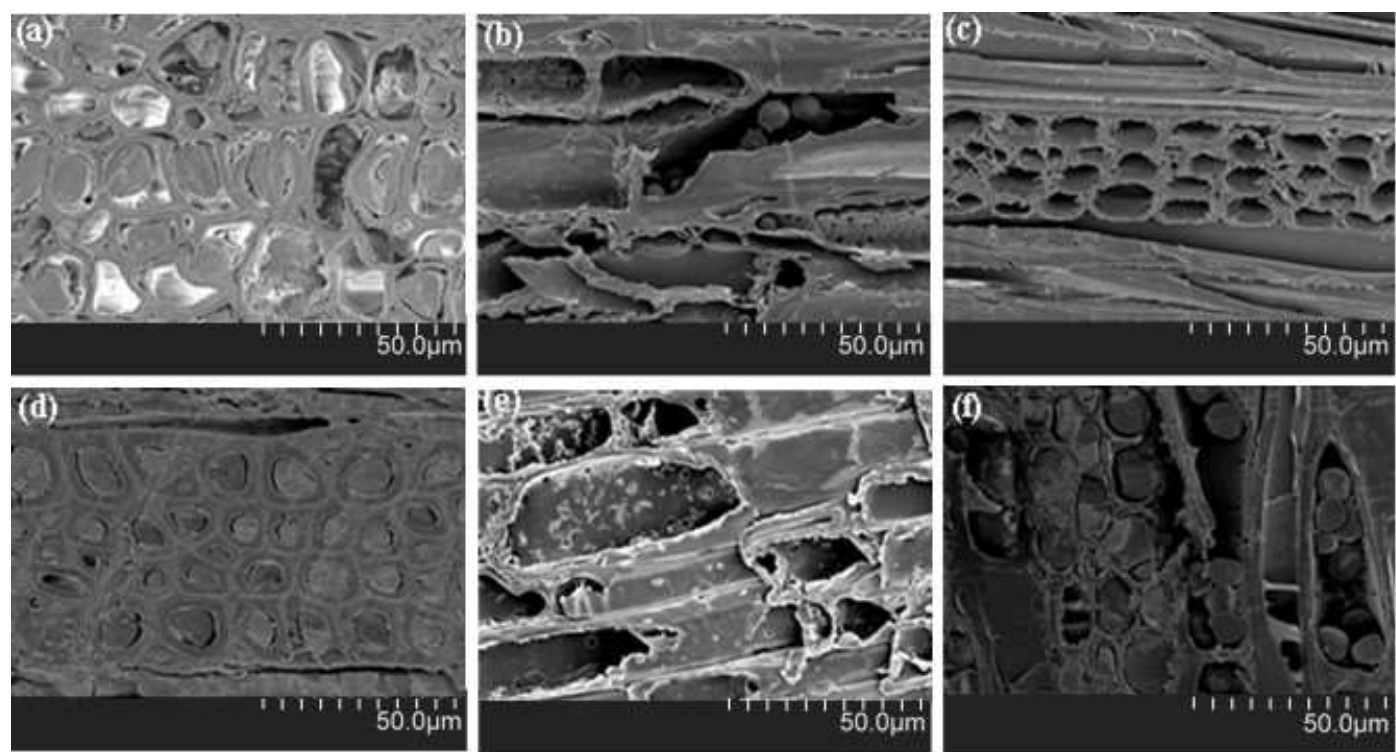

Fig. 4. The SEM micrograph of the silica sol-treated wood samples: (a) cross section, (b) radial section, and (c) tangential section. The SEM micrograph of the S-20\% GMU-treated wood samples: (d) cross section, (e) radial section, and (f) tangential section 


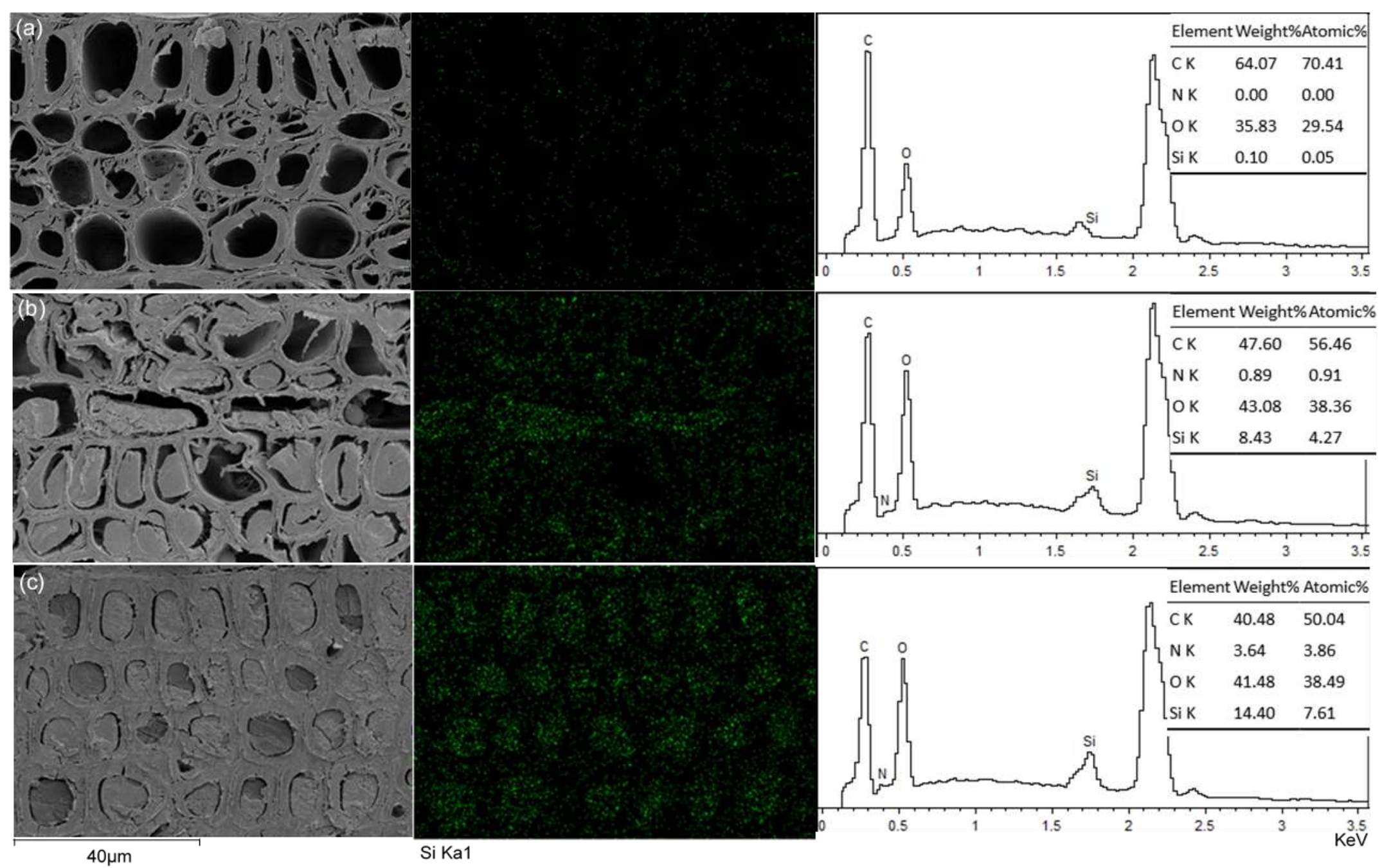

Fig. 5. The SEM-EDX analyses of the distribution of silicon and other elements in the untreated wood (a), silica sol-treated wood (b), and S-20\% GMUtreated wood samples (c) 
The SEM images of the cross sections, radial sections, and tangential sections of the silica sol-treated wood samples and the S-20\% GMU-treated wood samples are shown in Fig. 4. The SEM images showed that the treatment solution was taken up and fixed into the wood matrix. Most of the treatment solution was deposited in the cell lumen, while portions of it coated the surface of the cell wall after the treatment. For the S-20\% GMU treated wood samples, more of the silica sol-GMU aqueous solution filled in the cell lumen and attached to the surface of the cell wall than did in the silica sol-treated wood samples. And the polymer is well-distributed in the wood cell lumen and cell wall. This may act as barrier to prevent water molecule to penetrate the wood structure which is probably due to the deposition of some resin solid content in the lumen of cells in the wood.

The SEM-EDX analyses of the distribution of silicon and other elements in the untreated wood (a), silica sol-treated wood (b), and S-20\% GMU-treated wood samples (c) are shown in Fig. 5. There was only a small amount deposited in the cell walls of the untreated wood samples, which was probably due to exposure to silicon during sample treatment (as shown in Fig. 5a). Based on SEM-EDX results, silicon content was about $0.10 \%$; however, Si were $8.43 \%$ and $14.40 \%$ in the silica sol-treated wood and S-20\%GMU treated wood, respectively. Silicon was not only successfully introduced into the wood cell lumens, but also into the cell walls, thus influencing the mechanical properties of the modified wood. There was a greater amount of Si deposited in the cell lumen and cell wall of the S-20\% GMU-treated wood samples compared to the silica sol-treated wood samples. This was due to the fact that the GMU resin had a positive effect on silicon fixation in the wood matrix. In addition, the weight of the total nitrogen in the S-20\% GMU treated wood samples increased when compared to the silica sol-treated wood samples. This could be attributed to the composition of the GMU resin containing melamine and urea.

\section{CONCLUSIONS}

1. Rubber wood was modified with both a combination of silica sol and glyoxal melamine urea (S-GMU). The physical and mechanical properties of modified materials were improved. This process of rubber wood using GMU and silica sol is feasible for the preparation of an effective product with improved properties.

2. SEM-EDX analyses showed that the silica sol-GMU aqueous solution was incorporated into wood and diffused in the wood lumen and cell walls. The GMU resin had a positive effect on silicon fixation in the wood matrix. FTIR results showed that the presence of $\mathrm{C}-\mathrm{N}$ and $\mathrm{Si}-\mathrm{O}-\mathrm{Si}$ bonds in the S-GMU treated wood samples was detected.

3. The TGA analysis showed that the total mass loss that occurred during thermal decomposition of the S-GMU treated wood samples was lower than the untreated wood samples, and the thermostability of the S-GMU treated wood increased more than the S-GU treated wood samples.

4. All mechanical properties of the modified wood samples improved further, facilitated by the silica sol unique three-dimensional network, and favourable properties (flame resistance and high stability). The silica sol-GMU aqueous solutions were deposited in the cell lumen and the cell wall, which could block the path available for water access

Ping et al. (2020). "Properties of modified rubber wood," BioResources 15(4), 8051-8064. 8061 
to cell walls, which could result in a deceleration of moisture sorption and improve the anti-swelling efficiency.

\section{ACKNOWLEDGMENTS}

This research was funded by the Central Public - Interest Scientific Institution Basal Research Fund (Grant No.CAFYBB2017ZX003-04).

\section{REFERENCES CITED}

Berube, M.-A., Schorr, D., Ball, R. J., Landry, V., and Blanchet, P. (2018).

"Determination of in situ esterification parameters of citric acid-glycerol based polymers for wood impregnation," Journal of Polymers and the Environment 26, 970979. DOI: $10.1007 / \mathrm{s} 10924-017-1011-8$

Cai, X., Riedl, B., Zhang, S. Y., and Wan, H. (2007). "Effects of nanofillers on water resistance and dimensional stability of solid wood modified by melamine-ureaformaldehyde resin," Wood and Fiber Science: Journal of the Society of Wood Science and Technology 39(2), 307-318.

Deka, M., and Saikia, C. N. (2000). "Chemical modification of wood with thermosetting resin: Effect on dimensional stability and strength property," Bioresource Technology 73(2), 179-181. DOI: 10.1016/S0960-8524(99)00167-4

Deng, S., Du, G., Li, X., and Xie, X. (2014a). "Performance, reaction mechanism, and characterization of glyoxal-monomethylol urea (G-MMU) resin," Industrial \& Engineering Chemistry Research 53(13), 5421-5431. DOI: 10.1021/ie404278d

Deng, S., Pizzi, A., Du, G., Zhang, J., and Zhang, J. (2014b). "Synthesis, structure, and characterization of glyoxal-urea-formaldehyde cocondensed resins," Journal of Applied Polymer Science 131(21), 1-10. DOI: 10.1002/app.41009

Devi, R. R., and Maji, T. K. (2012). "Effect of nano-SiO 2 on properties of wood/polymer/clay nanocomposites,” Wood Science and Technology 46(6), 11511168.

Donath, S., Militz, H., and Mai, C. (2006). "Creating water-repellent effects on wood by treatment with silanes," Holzforschung 60(1), 40-46. DOI: 10.1515/HF.2006.008

Dong, Y., Yan, Y., Zhang, S., and Li, J. (2014). "Wood/polymer nanocomposites prepared by impregnation with furfuryl alcohol and nano- $\mathrm{SiO}_{2}$," Bioresources 9(4), 6028-6040. DOI: 10.15376/biores.9.4.6028-6040

GB/T 1934.2 (2009). "Method for determination of the swelling of wood," Standardization Administration of China, Beijing, China.

GB/T 1936.1 (2009). "Method of testing in bending strength of wood," Standardization Administration of China, Beijing, China.

GB/T 1936.2 (2009). "Method for determination of the modulus of elasticity in static bending of wood," Standardization Administration of China, Beijing, China.

Hill, C. A. S. (2007). Wood Modification: Chemical, Thermal and Other Processes, John Wiley \& Sons, Inc., Hoboken, NJ. 
Hu, Y. H., Chen, C. Y., and Wang, C. C. (2004). "Viscoelastic properties and thermal degradation kinetics of silica/PMMA nanocomposites," Polymer Degradation \& Stability 84(3), 545-553.

Jiang, J., Cao, J., and Wang, W. (2018). "Characteristics of wood-silica composites influenced by the $\mathrm{pH}$ value of silica sols," Holzforschung 72(4), 311-319. DOI: 10.1515/hf-2017-0126

Kumar, A., Ryparovà, P., Petrič, M., Tywoniak, J., and Hajek, P. (2017). "Coating of wood by means of electrospun nanofibers based on $\mathrm{PVA} / \mathrm{SiO}_{2}$ and its hydrophobization with octadecyltrichlorosilane (OTS)," Holzforschung 71(3), 225231. DOI: $10.1515 / \mathrm{hf}-2016-0108$

Lee, E. S., and Kim, S. I. (2005). "Effect of additives on durable-press cotton fabrics treated with a glyoxal/glycol mixture," Journal of Applied Polymer Science 96(4), 975-978. DOI: 10.1002/app.20751

Liu, F., Gao, Z., Zang, D., Wang, C., and Li, J. (2015). "Mechanical stability of superhydrophobic epoxy/silica coating for better water resistance of wood," Holzforschung 69(3), 367-374. DOI: 10 10.1515/hf-2014-0077

Mai, C., and Militz, H. (2004). "Modification of wood with silicon compounds. Inorganic silicon compounds and sol-gel systems: A review," Wood Science and Technology 37(6), 339-349. DOI: 10.1007/s00226-003-0205-5

Min, D. W. (2019). "Effect of nano copper-zinc preservative combined with phenolic resin on properties of rubber wood," Journal of Forestry Engineering 33(1), 39-44.

Nakano, T. (1993). "Reaction of glyoxal and glyoxal/glycol with wood," Wood Science and Technology 28(1), 23-33. DOI: 10.1007/BF00193873

Navarrete, P., Pizzi, A., Rode, K., Vignali, M., and Pasch, H. (2013). "MALDI-TOF study of oligomers distribution in spray-dried glyoxalated lignin for wood adhesives," Journal of Adhesion Science and Technology, 27(5-6), 586-597. DOI: 10.1080/01694243.2012.690618

Qin, S., Li, X., Li, M., and Li, J. (2017). "Present situation, prospect and suggestion of Chinese rubber wood modification technology," Tropical Agric. Eng. 41(4), 69-72.

Qu, H., Wu, W., Wu, H., Xie, J., and Xu, J. (2011). "Study on the effects of flame retardants on the thermal decomposition of wood by TG-MS," Journal of Thermal Analysis and Calorimetry 103(3), 935-942.

Saka, S., Sasaki, M., and Tanahashi, M. (1992). "Wood-inorganic composites prepared by sol-gel processing, 1: Wood-inorganic composites with porous structure," Journal of the Japan Wood Research Society 38(11), 1043-1049.

Salla, J., Pandey, K. K., Prakash, G. K., and Mahadevan, K. M. (2012). "Photobleaching and dimensional stability of rubber wood esterified by fatty acid chlorides," Journal of Wood Chemistry and Technology 32(2), 121-136. DOI:

10.1080/02773813.2011.624665

Sun, B., Chai, Y., Liu, J., and Miltitz, H. (2019). "Acetylation of plantation softwood without catalysts or solvents," Wood Research 64(5), 799-810.

Tejado, A., Peña, C., Labidi, J., Echeverria, J. M., and Mondragon, I. (2007). "Physicochemical characterization of lignins from different sources for use in phenolformaldehyde resin synthesis," Bioresource Technology 98(8), 1655-1663. DOI: 10.1016/j.biortech.2006.05.042

Temiz, A., Terziev, N., Jacobsen, B., and Eikenes, M. (2006). "Weathering, water absorption, and durability of silicon, acetylated, and heat-treated wood," Journal of Applied Polymer Science 102(5), 4506-4513. DOI: 10.1002/app.24878

Ping et al. (2020). "Properties of modified rubber wood," BioResources 15(4), 8051-8064. 8063 
Wang, F., Liu, J., and Lv, W. (2017). "Thermal degradation and fire performance of wood treated with PMUF resin and boron compounds," Fire and Materials 41(8), 1051-1057. DOI: 10.1002/fam.2445

Yan, Y., Dong, Y., Li, J., Zhang, S., Xia, C., Shi, S. Q., and Cai, L. (2015).

"Enhancement of mechanical and thermal properties of poplar through the treatment of glyoxal-urea/nano-SiO 2 ," RSC Advances 5(67), 54148-54155. DOI: $10.1039 / \mathrm{c} 5 \mathrm{ra0} 07294 \mathrm{~h}$

Younesi-Kordkheili, H., and Pizzi, A. (2016). "Acid ionic liquids as a new hardener in urea-glyoxal adhesive resins," Polymers 8(3), 57-71. DOI: 10.3390/polym8030057

Younesi-Kordkheili, H., and Pizzi, A. (2017). "Ionic liquids as enhancers of urea-glyoxal panel adhesives as substitutes for urea-formaldehyde resins," European Journal of Wood and Wood Products 75(3), 481-483. DOI: 10.1007/s00107-016-1116-0

Yue, K., Liu, W., Chen, Z., Lu, X., and Lu, W. (2016). "Investigation of the creep property of fast-growing poplar wood modified with low molecular weight resins," BioResources 11(1), 1620-1633. DOI: 10.15376/biores.11.1.1620-1633

Article submitted: January 28, 2020; Peer review completed: August 24, 2020; Revised version received and accepted: September 1, 2020; Published: September 7, 2020.

DOI: $10.15376 /$ biores. 15.4.8051-8064 